\title{
THE EFFECT OF IRRIGATION INTERVAL AND SOIL TYPE ON PASTURE AND LUCERNE PRODUCTION
}

Templeton Agricultural Research Station, MAF

Abstract

The responses of pasture and lucerne to irrigation were compared in 2 series of trials (1976-1981 and 1980-1984) on 8 different Canterbury soils. Pasture responses were also measured on a further 4 soils. With unrestricted irrigation, pasture yields were similar (about 11 t DM/ha/yr) on 8 of the 12 soils. These soils ranged from stone free Wakanui clay loams to a very stony Balmoral silt loam. Two soils yielded at a higher level, and two very stony soils significantly less. Non-irrigated lucerne yielded more than pasture in "average" Canterbury seasons, but less in two exceptionally dry years. With irrigation, lucerne yielded more than pasture for the first 2 or 3 years but tended to decline thereafter. The paper discusses irrigation strategies for border strip irrigated pastoral farms in times of water restrictions. It concludes that maximum DM production is likely to be obtained by spreading the available water over all irrigated pasture untii the irrigation interval reaches 23 to 28 days on shallow stony soils and 34 to 38 days on higher water holding capacity soils.

Keywords: pasture production, lucerne production, irrigation, irrigation interval, Canterbury.

\section{INTRODUCTION}

Irrigation has been spreading rapidly on the Canterbury Plains over the last 10 years and plans are being made to irrigate as much of the remaining flat land as water supplies and economic profitability will permit. However, the competition for water is greater than it has ever been (e.g. the Rakaia River National Conservation Order Application, 1984) and the cost of irrigation development has been rising faster than returns on agricultural production. Consequently for future irrigation development it is becoming increasingly important to identify and give priority to soils which will provide the greatest return per unit of water applied.

This paper summarises the results of 2 series of trials in Canterbury covering 12 different soils. The trials were designed so that valid comparisons could be made of pasture and lucerne productivity and response to irrigation on the different soils. However, since the pastures were not grazed, absolute yields may be as much as $20 \%$ lower than could be obtained under grazing.

\section{YIELD RESPONSES TO IRRIGATION ON DIFFERENT SOILS} Pasture

The first series of trials ran from 1976 to 1981 on 8 sites in Mid-Canterbury. Details of the trial methods are reported in Hayman \& McBride (1984). The essential points were that all sites in the trial were treated in a similar manner to facillate comparisons. Each plot consisted of an $8 \mathrm{~m} \times 4 \mathrm{~m}$ level basin surrounded by $100 \mathrm{~mm}$ high levees. All sites were sown simultaneously with the same pasture mixture $(20 \mathrm{~kg}$ Nui ryegrass, $3 \mathrm{~kg}$ Huia white clover, and $3 \mathrm{~kg}$ Mount Barker subterannean clover/ha). Initially lime was applied where necessary to bring the $\mathrm{pH}$ to 5.8 , and superphosphate and potassium chloride applied annually in winter following soil tests. However, the superphosphate available at the time of the trial was of poor quality so that even with 
applications of $375 \mathrm{~kg} / \mathrm{ha}$ to $500 \mathrm{~kg} / \mathrm{ha}$ of flowmaster superphosphate, Olsen P levels remained in the range of $7-13$.

Pastures were not grazed. They were cut approximately monthly with a reel mower and the clippings returned to maintain fertility.

Irrigation was applied by flooding individual basins with approximately $100 \mathrm{~mm}$ of water whenever the surface $100 \mathrm{~mm}$ of soil reached a pre-determined soil moisture content (Fig. 1).

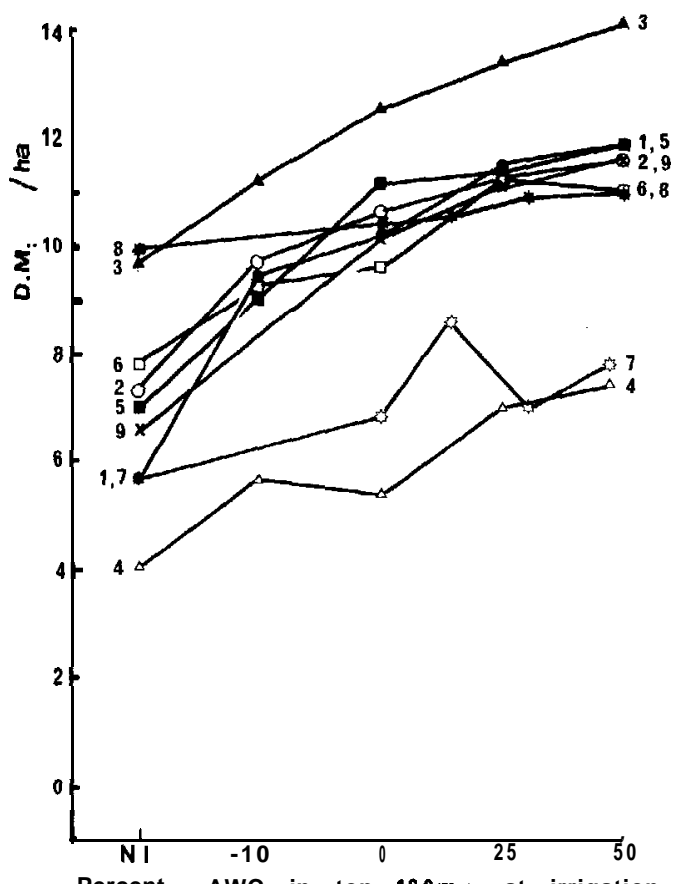

Figure 1: Pasture response to irrigation; first series. Sites 7and 8 mean of 4 years, all others mean of 5 years. (1 = Eyre stony silt loam; 2 = Wakanui clay loam (shallow); 3 = Wakanui clay loam (deep); 4 = Lismore very stony silt loam; 5 = Eyre silt loam; 6 = Wakanui clay loam; $7=$ Ruapuna very stony silt loam; $8=$ Mayfield silt loam; $9=$ Lismore stony silt loam (Winchmore).)

The mean yields over the 5 years on each of the 8 soils are plotted in Fig. 1. Also plotted on Fig. 1 are the yields from similar irrigation treatments at Winchmore Irrigation Research Station (data from D.S. Rickard). The outstanding features of this graph are:

1. Six soils, ranging from a stone free Wakanui clay loam to a stony Eyre silt loam, and including the Lismore stony silt loam at Winchmore, all supported a similar level of pasture production (approximately $11 \mathrm{t}$ DM/ha/yr) when irrigation was unrestricted.

2. One soil, a free draining Wakanui clay loam produced significantly more than all the others at all levels of irrigation.

3. Two soils, a Lismore very stony silt loam at Valetta, and a Ruapuna very stony silt loam at Methven, produced significantly less pasture DM even when irrigated liberally. 
4. The pattern of response to irrigation was similar on all soils in moderate to low rainfall areas. The two exceptions, Mayfield silt loam (8) and Ruapuna very stony silt loam (7), were situated in a high rainfall area where the response to irrigation was excepted to be low.

The second, more recent series of trials was established on 4 sites, 2 in the new Waiau Irrigation Scheme in North Canterbury and 2 in the area of the proposed Lower Rakaia Irrigation Scheme in Mid-Canterbury. These trials were also established on level basins and managed in the same manner as the first series. The only difference was that the decision on when to irrigate was modified to simulate more closely the roster system of community irrigation schemes. Hence water was applied to different treatments every $2,3,4,5$, or 6 weeks, provided the soil was not already wet on the due "roster" day (i.e. the top $100 \mathrm{~mm}$ did not contain more than $60 \%$ of its available water holding capacity). These trials were sown in 1980 and data from the two post-establishment years, 1981182 and 1982183, are presented in Fig. 2. Also presented in this figure is the production over the same 2 seasons of the only two comparable treatments of the Winchmore trial referred to above i.e. the non-irrigated and 3-weekly irrigated treatments. The features of this graph are:

1. Pasture on 3 of the trial soils, and the Winchmore Lismore soil, yielded approximately $11 \mathrm{t}$ DM/halyr when adequately irrigated. However, the stony Balmoral and Lismore soils failed to equal the deeper Chertsey soil at Rakaia when the irrigation interval was more than !wo weeks.

2. One soil, a Chertsey silt loam at Waiau, produced at a significantly higher level at all irrigation intervals.

3. The Chertsey soils both showed a greater response to infrequent irrigation than the stony soils.

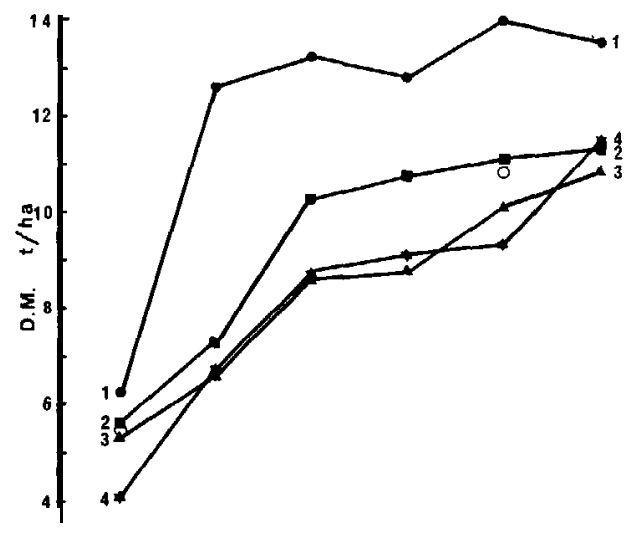

2

$t_{t}$

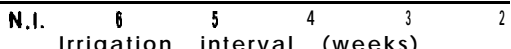

Figure 2: Pasture response to irrigation; Second series. Mean of 2 years. $(1=$ Chertsey silt loam (Waiau); 2 = Chertsey silt loam (Rakaia); 3 = Lismore stony silt loam (Rakaia); $4=$ Balmoral very stony silt loam. $0=$ Lismore stony silt loam (Winchmore).) 
The soils from these two sets of trial data fall into 3 distinct categories according to their yields under irrigation:

Superior:

Wakanui clay loam, (Wakanui, free draining, $900 \mathrm{~mm}$ to stones).

Chertsey silt loam, (Waiau, $750 \mathrm{~mm}$ to stones).

Average:

Wakanui clay loam, (Wakanui, $450 \mathrm{~mm}$ to stones, free draining)

Wakanui clay loam, (Lagmhor, no stones, water-logged in winter)

Eyre silt loam, (Lagmhor, $450 \mathrm{~mm}$ to stones)

Mayfield silt loam, (Methven, $600 \mathrm{~mm}$ to stones)

Eyre stony silt loam, (Wakanui, stones to surface)

Lismore stony silt loam, (Winchmore, stones to surface)

Balmoral very stony silt loam, (Waiau, stones to surface)

Chertsey silt loam, (Rakaia, $600 \mathrm{~mm}$ to stones)

Inferior:

Lismore very stony silt loam, (Valetta, stones to surface)

Ruapuna very stony silt loam, (Methven, stones to surface)

It is not known why one Wakanui and one Chertsey soil produced so much more than other soils of the same classification. However, it is likely that these superior soils are relatively rare in Canterbury as yields of this level are not often recorded from continuously mown (ungrazed) pastures.

The inferior soils are both excessively stony, with stones constituting over $50 \%$ of the volume of the profile. However, the Balmoral soil, with a similar stone content, produced at an average level. This is probably due to the quality of the matrix material between the stones. Soils should not be judged on stone content alone.

\section{Lucerne}

Lucerne trials were run concurrently with pasture using the same range of irrigation treatments at each of the 12 sites. However, lucerne failed to persist on 4 sites; it was smothered with clover at two high rainfall sites, succumbed to couch (Agropyron repens) at one site and was drowned out at the fourth site. Like pasture, lucerne was sown in level basins. It was cut 4 times per year in November, January, February/March and May and all clippings were removed. Fertility was maintained by applying $500-650 \mathrm{~kg} / \mathrm{ha}$ of superphosphate and $500 \mathrm{~kg} / \mathrm{ha}$ of potassium choloride annually.

Lucerne is a forage plant which is known for its ability to produce more than pasture in dry conditions. Consequently it is worthwhile comparing the relative yields of non-irrigated pasture and lucerne on the same soils in average and very dry seasons. (Too much reliance should not be placed on the absolute yield comparison because different cutting techniques and intervals were used for each species. However, since the "techniques were constant over all sites and seasons, comparisons of relative yields between seasons are valid.)

For the first series of trials run over the "average" rainfall seasons 1976-81, nonirrigated lucerne outyielded pasture on all soils (Table 1). In the second series of trials, two seasons, $1981 / 82$ and 1982183, were exceptionally dry and lucerne yielded less than pasture (Table 1). However, in the wet season, 1983184 lucerne again outyielded pasture on all but the Balmoral soil. (Both irrigated and dry lucerne has yielded less than pasture on this soil in all years).

The explanation for the relatively poor performance of lucerne in the two exceptionally dry years in the 2nd series appears to lie in the timing of the drought. Conditions were dry to very dry for practically all of the warm season (October to March) in both years. This is the time of the year when lucerne makes its growth. In contrast pasture was able to grow, if somewhat slowly, in the cooler conditions of late autumn, winter and early spring when moisture supplies were more adequate, and lucerne was dormant because of the low.temperatures. 
Table 1: NON-IRRIGATED PASTURE AND LUCERNE PRODUCTION IN CANTERBURY. (t DM/ha).

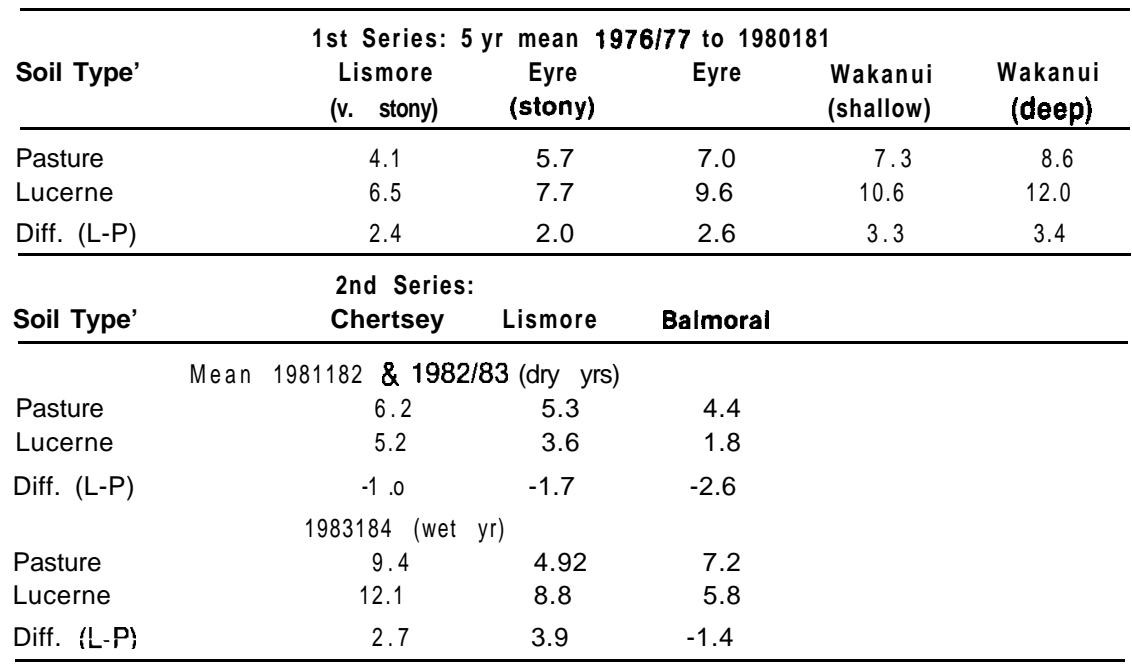

1 Arranged in order of increasing AWC to $900 \mathrm{~mm}$.

2 New pasture

In the "average" rainfall years (first series and 1983184 in the 2nd series) lucerne made significant growth in the warm wet periods, and carried on growing longer into the dry periods because of its ability to draw more water from deeper in the profile.

When irrigated, lucerne yields were equal or higher than pasture on 7 of the 8 sites where it grew (Table 2). (It also failed on 4 sites where pasture succeeded). However, the $5 \mathrm{yr}$ averages of the first series conceal the fact that lucerne substantially outyielded pasture in the first 2-3 yrs but declined thereafter to lower yields than pasture in the 5th year (Hayman \& McBride 1984).

Table 2: IRRIGATED PASTURE AND LUCERNE IN CANTERBURY. (t DM/ha).

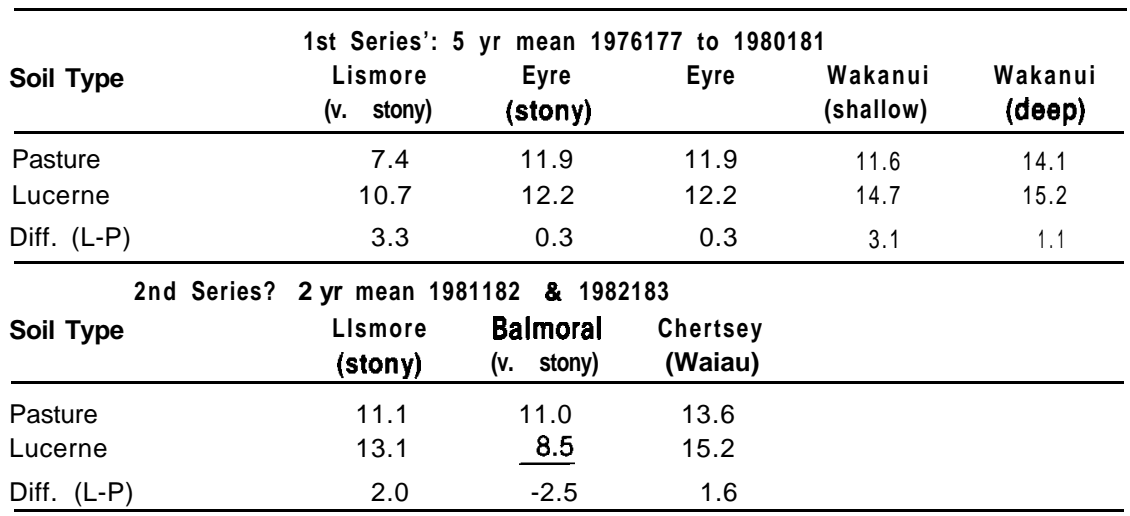

1 Irrigated when top $100 \mathrm{~cm}$ dried to $50 \%$ ASM.

2 Irrigated P-weekly 


\section{EFFECT OF IRRIGATION INTERVAL}

With the increasing scarcity of water and cost of irrigation there is a strong incentive to make the available water cover as large an area as possible. Both border and sprinkler irrigators can do this by increasing the interval between irrigations so that more paddocks can be covered in each watering cycle. Sprinkler irrigators also have the option of applying less water at each irrigation.

The second series of trials was designed to measure the effect of varying the irrigation interval. The amount of water applied was constant at $100 \mathrm{~mm}$ per irrigation, effectively simulating a border strip system.

The 2 year mean yields for each soil type are presented in Fig. 3. They have been separated into spring, summer, autumn and winter because there were important seasonal differences in the response.

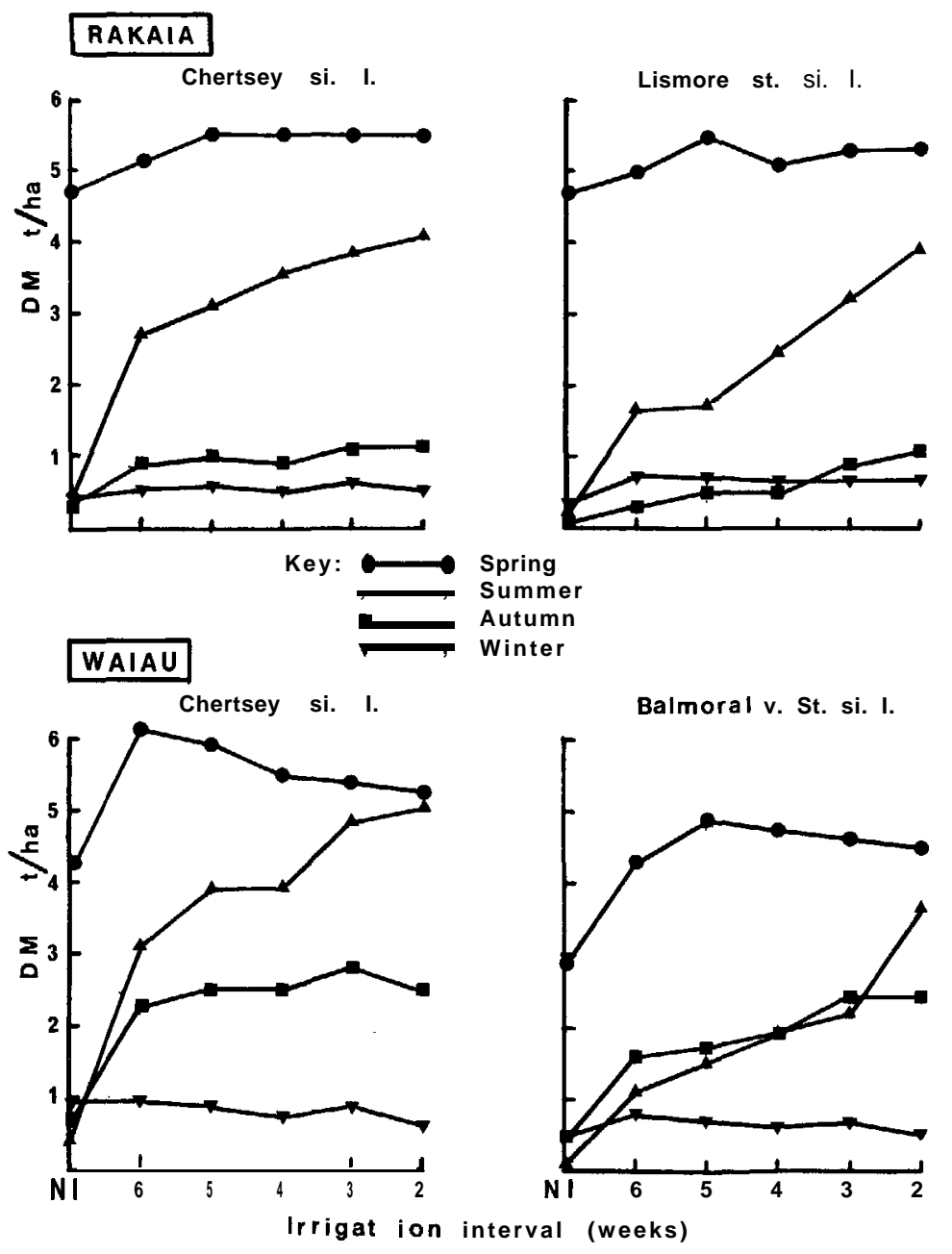

Figure 3: Pasture response to irrigation in spring, summer, autumn and winter; Second series. Mean of 2 years. 
Spring (September, October, November)

Although these were drier than normal springs, there was no advantage in irrigating more often than every 5 or 6 weeks at any site. In fact there is some indication that more frequent irrigation may actually reduce spring production in the Waiau area. (This may be a leaching effect which would be less likely to occur if a sprinkler system was used and care was taken to apply no more than the deficit at each irrigation).

Summer (December, January, February)

The shorter the irrigation interval in summer, the higher the yield on all soils. As there is no sign of a levelling off in the response, it is possible that intervals even shorter than 2 weeks may have increased yields further in these very dry summers. Autumn (March, April, May)

The response to more frequent irrigation was less than anticipated. 5-6 weekly irrigation was adequate on the Chertsey soils, but 3 weekly irrigation was better on the stony Lismore and Balmoral soils.

Winter (June, July, August)

Irrigation had no carry-over effect on winter production.

\section{Implications for Water Management}

These results have implications for irrigation water management on Canterbury farms.

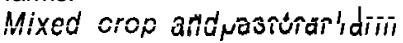

Since pasture only required irrigation every 5 or 6 weeks in spring, water is most profitably concentrated on the crops at this time. However, every effort should be made to get everything irrigated in November to minimise the intense competition for water in December when the needs of both crops and pastures are high (Stoker 1979). As crop needs decline in January, concentrate the water on pasture. If possible choose crops and planting dates that minimise the conflict for water in December. All-grass farm

Water will be limiting in summer on most all-grass farms. In some years this situation will be made worse by restrictions on water withdrawal from rivers or reduced yield from wells. Consequently, pastoral farmers often have to decide whether to extend the roster interval and accept some yield reduction on all paddocks, or maintain an optimum interval and maximum production on part of the farm, by leaving some paddocks unirrigated.

Since this problem is only likely to occur in summer, summer data from the 4 sites in the time based irrigation trials (second series) have been analysed to obtain an answer to this question (Fig. 4 and Table 3).

Fig. 4 shows the regression relationship between irrigation interval and summer pasture DM production on the 4 soils. These relationships have been used to calculate the summer DM production to be expected on a 100 ha farm on each of the soils (Table 3 ). Production has been calculated for 5 water supply situations; i.e. when there is enough water to irrigate the whole farm every $17,23,26,34$ or 42 days over summer. (17 days is the design interval for the Waiau scheme and 23 days is one suggestion for the design interval on the proposed Lower Rakaia scheme. Both schemes can expect less than design water supply in dry summers.) Pasture production for the whole farm has been calculated for situations when the available water is either spread over all the pasture or restricted to parts of it.

When water supply is plentiful, maximum production in summer is obtained by irrigating as frequently as every 14 days (Fig. 4). More frequent irrigation was not tested but may have produced even higher yields.

When summer water supply is restricted, maximum farm pasture production would be obtained with a 23 day irrigation interval on the stony Lismore and Balmoral soils, or a 34 day interval on the higher water holding capacity Chertsey soils (Table 
3). Table 3 also shows that the effect of extending this maximum interval by 3 or 4 days is very small. Therefore it is recommended that in most situations the maximum interval on low water holding capacity stony soils should be about 4 weeks and on deeper soils between 5 and 6 weeks.

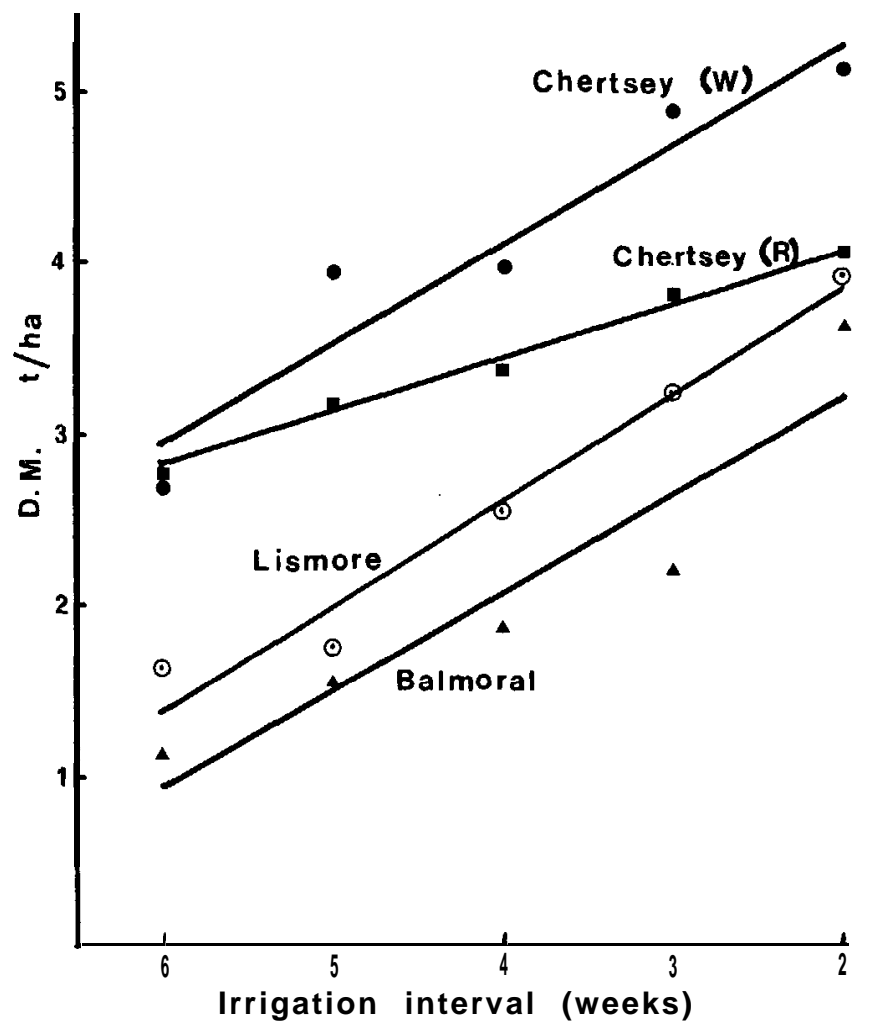

Figure 4: Relationship between irrigation interval and pasture response to irrigation in Summer. Equations of the regression lines are:
Chertsey (W)
$D M=4.12-0.585(X-4)$
$R=0.95$
Chertsey $(R)$
$D M=3.47-0.332(X-4)$
$R=0.99$
Balmoral
$D M=2.08-0.566(X-4)$
$R=0.94$
Lismore
$D M=2.62 \cdot 0.613(X-4)$
$\begin{aligned} R & =0.94 \\ R & =0.98\end{aligned}$

Where $X=$ irrigation interval in weeks.

An important reason behind this recommendation is that pasture left dry through a summer drought becomes dormant and does not respond to small showers of rain. When significant rain falls, or irrigation is restored, such pasture takes up to two weeks to begin growing again. In contrast, pasture which has suffered moisture deficiency but has been watered often enough to prevent it becoming dormant, responds immediately to every shower or irrigation. This effect has not been taken into account in the calculations for Table 3.

A caution: the above data were obtained from pastures receiving $100 \mathrm{~mm}$ of water at each irrigation. They are not directly applicable to sprinkler irrigated pasture receiving only 50-60 $\mathrm{mm}$ at each irrigation. Such pastures will require irrigating more frequently. 
Table 3: PASTURE DM PRODUCTION (t DM) OVER SUMMER ON A 100 HA FARM WHEN IRRIGATED WITH SYSTEMS OF VARYING CAPACITY.

\begin{tabular}{|c|c|c|c|c|c|c|c|}
\hline $\begin{array}{l}\text { System } \\
\text { capacity } \\
\text { (ha/day) }\end{array}$ & $\begin{array}{c}\text { Irrigation } \\
\text { interval } \\
\text { (days) }\end{array}$ & $\begin{array}{r}\text { A } \\
\text { Irrig } \\
\text { (ha) }\end{array}$ & $\begin{array}{l}\text { ea } \\
\text { Dry } \\
\text { (ha) }\end{array}$ & $\begin{array}{c}\text { Chertsey } \\
\text { (W) }\end{array}$ & $\begin{array}{c}\text { Chertsey } \\
\text { (R) }\end{array}$ & Lismore & Balmoral \\
\hline 5.9 & 17 & 100 & 0 & 500 & 400 & 360 & 300 \\
\hline \multirow[t]{2}{*}{4.3} & 23 & 100 & 0 & 450 & 370 & 310 & 250 \\
\hline & 17 & 74 & 26 & 420 & 330 & 280 & 220 \\
\hline \multirow[t]{3}{*}{3.6} & 28 & 100 & 0 & 410 & 350 & 260 & 210 \\
\hline & 23 & 83 & 17 & 400 & 330 & 270 & 220 \\
\hline & 17 & 60 & 40 & 370 & 300 & 260 & 210 \\
\hline \multirow[t]{4}{*}{2.9} & 34 & 100 & 0 & 360 & 320 & 210 & 160 \\
\hline & 28 & 81 & 19 & 360 & 310 & 230 & 190 \\
\hline & 23 & 67 & 33 & 360 & 300 & 240 & 190 \\
\hline & 17 & 50 & 50 & 330 & 270 & 230 & 180 \\
\hline \multirow[t]{5}{*}{2.4} & 42 & 100 & 0 & 300 & 280 & 140 & 100 \\
\hline & 34 & 82 & 18 & 330 & 290 & 190 & 140 \\
\hline & 28 & 67 & 33 & 330 & 280 & 210 & 160 \\
\hline & 23 & 55 & 45 & 320 & 270 & 210 & 170 \\
\hline & $\mathrm{i} i$ & 40 & 60 & 300 & 250 & 200 & 160 \\
\hline
\end{tabular}

\section{SUMMARY}

Similar pasture yields can be expected from a wide range of soils in Canterbury when adequate irrigation is supplied. There are some elite soils capable of higher production and an unknown area of very stony soils whose yield under irrigation appears to be limited.

In "average" Canterbury seasons unirrigated lucerne will outproduce pasture, but in exceptional years, when the drought begins in spring when soil temperatures are still low, lucerne may fail.

Irrigated lucerne will out-produce pasture for up to 5 years on most soils, but eventually productivity falls below pasture.

On border strip irrigated pastures, when summer water supplies are restricted, maximum DM production is likely to be obtained by extending the irrigation interval to about 4 weeks on low water holding capacity stony soils, or to between 5 and 6 weeks on higher water holding capacity soils.

\section{ACKNOWLEDGEMENTS}

Thanks are due to the farmers who willingly made land available for these trials. Also to S.D. McBride, J.D. Gray and K.M. Bartley who were responsible for the field work, and staff of the mowing team, herbage laboratory and soil physics laboratory at Winchmore Irrigation Research Station who collected or processed the samples.

\section{REFERENCES}

Hayman, J.M.; McBride, SD. 1984. Winchmore Irrigation Research Station, Technical Report No. 17. 80 p.

Rakaia River, National Water Conservation Order Application. 1984. Report of a National Water \& Soil Conservation Authority Committee appointed to examine and make recommendations on the application. $72 \mathrm{pp}$.

Stoker R. 1979. N.Z. Farmer, 700: (18) 38-41. 